\title{
A trial of devices for urinary incontinence following treatment for prostate cancer
}

\section{Author info:}

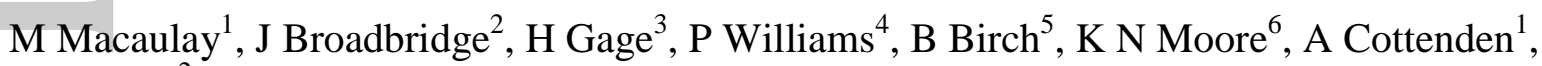
M J Fader ${ }^{2}$

1. Continence and Skin Technology Group, University College London, UK

2. Continence and Skin Technology Group, University of Southampton, UK

3. Department of Economics, University of Surrey, UK

4. Department of Mathematics, University of Surrey, UK

5. Dept. of Urology, University Hospital Southampton NHS Foundation Trust, Southampton, UK

6. University of Alberta, Edmonton, Canada

Author contact Information:

Margaret Macaulay m.macaulay@ucl.ac.uk

Jackie Broadbridge mbroadbrid@btinternet.com

Heather Gage h.gage@surrey.ac.uk

Peter Williams p.williams@surrey.ac.uk

Brian Birch Brian.Birch@aol.com

Katherine Moore Katherine.moore@ualberta.ca

Alan Cottenden a.cottenden@ucl.ac.uk

Mandy Fader m.fader@soton.ac.uk

Address for correspondence:

Margaret Macaulay

Continence and Skin Technology Group, UCL

$105 \mathrm{~A}, 1^{\text {st }}$ Floor Wolfson House

2-10 Stephenson Way

London NW1 2HE

m.macaulay@ucl.ac.uk

\footnotetext{
This article has been accepted for publication and undergone full peer review but has not been through the copyediting, typesetting, pagination and proofreading process, which may lead to differences between this version and the Version of Record. Please cite this article as doi: 10.1111/bju.13016
}

This article is protected by copyright. All rights reserved. 


\section{Objective}

\section{Abstract}

- To compare performance of three continence management devices and absorbent pads used by men with persistent urinary incontinence ( $>1 \mathrm{yr})$ post treatment for prostate cancer.

\section{Patients and Methods}

- Randomised, controlled trial of 56 men with one year follow up.

- Three devices were tested for three weeks each: sheath drainage system, body-worn urinal, penile clamp. Device and pad performance were assessed.

- Quality of life (QOL) was measured at baseline and follow-up with the King's Health Questionnaire.

- Stated (intended use) and revealed (actual use) preference for products was assessed

- Value-for-money was gathered.

\section{Results}

Substantial and significant differences in performance were found:

- Sheath: good for extended use (e.g. golf and travel) when pad changing is difficult. Good for keeping skin dry, not leaking, not smelling and convenient for storage and travel;

- Body-worn urinal: generally rated worse than the sheath and was mainly used for similar activities but by men who could not use a sheath (e.g. retracted penis); not good for seated activities.

- Clamp: good for short vigorous activities like swimming/exercise. Most secure, least likely to leak, most discreet but almost all men described it as uncomfortable or painful.

- Pads: good for everyday activities and best for night-time use. Most easy to use, comfortable when dry but most likely to leak and most uncomfortable when wet.

- A preference for having a mixture of products to meet daytime needs; around two thirds of men were using a combination of pads and devices after testing compared to baseline.

\section{Conclusions}

- This is the first trial to systematically compare different continence management devices for men

- Pads and devices have different strengths which make them particularly suited to certain circumstances and activities.

$\bullet$ use pads at night but would choose a mixture of pads and devices during the day.

- Device limitations were important but may be overcome by better design.

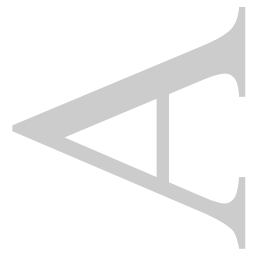

Key words: penile compression device; body worn urinal; sheath drainage system; King's Health Questionnaire; quality of life. 


\section{Introduction}

Prostate cancer is the commonest male cancer in the UK. ${ }^{1}$ Around $10-15 \%$ of men who undergo surgical or non-surgical treatment for prostate cancer will suffer lifelong urinary incontinence (UI). ${ }^{2-4}$ UI has major negative effects on quality of life and social interactions ${ }^{5-}$ ${ }^{11}$ and is associated with long term morbidities such as skin injury, urinary tract infection, falls, and increased hospital stays. ${ }^{12}$ For those who do not regain continence, absorbent pads or alternative products and devices are required to maintain social continence.

In addition to the usual choice of absorbent pads, other continence products include penile compression devices (clamp), sheath/condom drainage systems (sheath), and body-worn urinals (BWU). In the UK the latter two are available on NHS prescription. However their market share is low compared to the use of absorbent products despite recommendations that men should be offered male devices as well as pads ${ }^{12-14}$ and evidence that men may prefer sheaths to pads. ${ }^{15}$ The limited research on the comparative efficacy, strengths and limitations, is an important barrier to alternate device use. Thus, the objective of this study was to compare the performance of three continence management devices (penile clamp, sheath and body worn urinal) and absorbent pads used by men with on-going UI following prostate cancer treatment. The relative costs of providing the different products, and participants' views on value-for-money were also investigated.

\section{Patients and Methods}

Participants: Community dwelling men living in the Southern Counties in England who had been treated for prostate cancer, had persistent UI > 1 year, currently used at least one absorbent pad per day, and had satisfactory manual dexterity to apply and remove the devices. Exclusion criteria were: faecal incontinence and problems that might make the use of male devices unsafe i.e. a known latex allergy, reduced genital sensation and impaired cognitive function (MMSE <27). Ethics approval was given by Southampton and South West Hampshire REC; NHS governance approval was obtained from each of the NHS Trusts. Written informed consent was obtained from each participant.

\section{Trial Registration}

The trial was registered with the UK Clinical Research Network (No. 8975) and can be found at:

http://public.ukcrn.org.uk/Search/Portfolio.aspx?UKCRNStudyID=8975\&SearchType=Any

\section{Trial Design}

The study was a randomised cross-over trial using Latin Squares method ${ }^{16}$ with each participant testing the three devices in random order day and night for up to three weeks (except the clamp, which is not suitable for night use). A registered nurse expert in continence care visited participants in their homes at four data collection points. Baseline data included demographics, continence status, measures of independence (Barthel Index ${ }^{17}$ ), cognitive function (Folstein Mini-mental test exam ${ }^{18}$ ) and quality of life (King's Health Questionnaire $^{19}$ ). Figure 1 shows trial the design. 


\section{Primary Outcome: Overall Opinion Questionnaire}

The Overall Opinion Questionnaire was completed after all products had been tested; it was designed to elicit:

- overall opinion (rated on a 10 point visual analogue scale) for day or night use

- product acceptability (not acceptable /poor/ acceptable / good)

- advantages and disadvantages of the test products and the absorbent pad in regular use by the participant

- stated preferences (which products men planned to use post-test).

There were four secondary outcomes:

1. Product performance questionnaires were based on a previously tested tool used in a study of sheath use $\mathrm{e}^{22}$ and were piloted by seven men (5 using sheath or BWU; 2 using clamp) to ensure questions captured all relevant aspects of product performance. These were administered at the end of each product testing.

2. Quality of Life measured by King's Health Questionnaire (KHQ). This is a widely used validated instrument and is suitable for men and women. ${ }^{19,20}$ KHQ has weighted scores for nine dimensions ranging from 0 (best)-100 (worst). The lower the score the better the reported QOL. This data was collected at the end of each product testing and at 3 months post testing (Visit 5).

3. Revealed preferences (which products participants had actually been using vs planned use) and views about what the NHS should provide based on estimated cost to NHS of each device and pads, were obtained. Data was collected at Visit 5.

4. Perceived Value for Money was obtained through simplified questions following piloting of more complex versions. The costs of products derived from NHS Supply Chain catalogue $\mathrm{e}^{21}$ and from online formulary data ${ }^{22}$ were disclosed to participants to see if awareness of relative costs affected their stated preferences. Data was collected at Visit 5.

\section{Study Products (Figure 2)}

Pads: Participants used their current product supplied by the NHS. This was included as the baseline norm with which all participants were familiar. Our intent was to assess the perception of the test products relative to normal product use/standard of care.

Sheaths: The three most commonly used brands based on prescription analysis data ${ }^{23,24}$ were selected and participants were randomised to one of the three brands. Men with very light leakage had the option of connecting a valve to their sheath, rather than wearing a drainage bag.

BWUs: These were fitted by representatives from the two UK suppliers of these products (SG\&P Payne and Jade Euro Med Ltd.) as is normal practice. If fitting of one BWU was not successful, the alternate was tried. 
Clamps: The Cunningham clamp was selected because there is evidence that it is the most effective and is the only product with radiology testing of penile circulation. ${ }^{24}$

Sample size Target sample was 80 men to allow for the detection, with about $80 \%$ power, of a difference of $30 \%$ in Overall Opinion scores for any pair-wise comparison of products with an overall significance level, of at most, $5 \%$ for all such comparisons.

Randomisation: Randomisation was determined using a computer generated list into random block sizes of 6 . Participant assignments were given by the central study administrator to the local research nurse after consent and baseline data were obtained. Because of packaging, it was not possible to blind participants or research staff to products.

Statistical Methods: Background characteristics were described using summary statistics. The Chi-Squared test was used when comparing any two groups (e.g. Light incontinence vs Moderate/Heavy incontinence pad users) with regard to categorical variables. The paired ttest was used for assessing changes in continuous variables (e.g. number of pads used, product VAS score). The Friedman test was used for comparing the 4 products (Pads, BWU, Sheaths, Clamp) with regard to ordinal outcomes. When a statistically significant result was obtained, indicating that the 4 products did not all have the same ordinal outcome level, the McNemar test was used to compare each pair of products with regard to a binarised recoding of the ordinal outcome in question (a dichotomous grouping was selected in order to facilitate the readability of the final report). Repeated measures analysis of variance was used to compare the 4 products with regard to continuous outcomes such as VAS scores. Each pair of products was subsequently compared, with a Bonferroni adjustment to allow for multiple comparisons. The Spearman Rank correlation test was used for assessing the association between two ordinal variables, or between an ordinal variable and a continuous variable.

\section{Results}

\section{Participants}

Data collection occurred between December 2010 and April 2012. 3547 men living in South East England were contacted by mail via Continence Advisory Services, Urology outpatients and prostate cancer charities (an unknown number were invited via email and face to face by these organisations). 302 were screened for eligibility and 74 recruited; 18 either withdrew or were withdrawn (Figure 3); 56 had complete data at the end product testing. Baseline characteristics are summarised in Table 1 . The participants were predominantly retired, independent men whose quality of life was adversely affected by incontinence. Most had undergone radical prostatectomy $(n=44)$; the others were TURP plus radiotherapy $(n=2)$, HIFU $(n=4)$, radiotherapy $(n=6)$. Four men had had AUS inserted post radical prostatectomy. All reported stress incontinence. Eighteen did not use continence products at night. At study entry, more than half had previously tried out sheaths, but few had used BWUs and clamps. Men described their incontinence as 'light' or 'moderate' based on the number of pads used per day. Overall mean pad use per day was 2.9 (SD 1.82), median 3.0 (light incontinence 2.6 (SD 1.59), median 3.0; moderate incontinence 3.40 (SD 2.14, median 3.0).

\section{Products}

Overall Opinion after testing all products 
On a Visual Analogue Scale (Table 2A) pads were rated significantly higher than the other products in all situations. When comparing acceptability --- either 'good/acceptable' versus 'poor/not acceptable' --- pads were rated most highly compared with sheaths $(\mathrm{p}=0.031)$, clamps $(p=<0.000)$ and BWUs $(p=<0.000)$ (Table $2 B)$. Sheaths were more highly rated than BWUs $(\mathrm{p}=<0.014)$. For the criterion of 'good/acceptable versus 'poor/not acceptable', pads and sheaths are rated very similarly. Pads were significantly more acceptable than all the other products for day use at home; significantly more acceptable than BWU and clamps (but not sheaths) for day use away from home; sheaths were more acceptable than BWU for day home and day away use. At night pads were the most acceptable product.

\section{Product performance}

Feedback on product performance immediately after testing each product indicated some important differences between the four designs (Table 3). Although pads were rated highest for overall opinion, they were reported to leak the most but were the easiest product to apply and remove, and scored highly for comfort when dry (but not when wet). The sheath was generally rated better than the pad for leakage, odour, comfort when wet, ease of carrying and disposal, and better than the BWU for comfort when dry, comfort when wet, visibility, odour, ease of putting on and ease of carrying. The BWU was rated as being better than pads for comfort when wet, but worse than the sheath in all other aspects. It was also significantly worse than the sheath and clamp for impact on self-image. The clamp was rated better than the other three products for security, leakage and low impact on clothing choice, ease of application, better than the BWU and sheath for keeping the skin dry, and superior to pads for odour control. However the clamp caused the most pain.

\section{Stated and actual preferences}

When men were asked which products they planned to use in the future, most selected combinations for day use, but pads were the preferred product at night (Table 4). The proportion of men opting for a combination of products in the day was higher after testing all products than at baseline $(n=37,66.6 \%$ vs. $5,8.9 \%)$, the most popular combination being a pad and sheath (14/56 men) for use when away from home

Pad use in the day was lower at 3 month follow up than pre testing (mean (SD) pads per week (13.3 (10.8) vs. 16.7 (10.5), $\mathrm{p}=0.01)$, confirming some switching to other products, but there was no significant difference at night (5.1 (4.1) vs. 5.0 (4.2), $\mathrm{p}=0.87)$. The number reporting using a mix of products in the day had, however, dropped slightly from $37 / 56(66 \%)$ immediately post testing to $32 / 55(58 \%)$ three months later, but was still higher than at baseline $(\mathrm{n}=5)$.

Post study, ethical approval was received to contact participants to review their product use. At twelve months, 36 men were traced of whom 19 (53\%) stated they were still using combinations of products.

\section{Quality of Life (Table 5)}

Quality of life was measured at baseline, after each test period and at 3 months post testing. There was a significant improvement in quality of life (KHQ) immediately after trying out the sheath (score change $-4.0, \mathrm{p}=0.001,95 \%$ CIs -6.3 to -1.7 ) and the BWU (score change $-2.25, p=0.004,95 \%$ CIs -3.8 to -0.7 ). There was no difference in quality of life scores after trying out the clamp or for any devices at 3 month follow up compared to baseline. 


\section{Descriptive comments}

Participant comments reinforced the preference for a mix of products and the value of having a selection available.

"If I am at home and not engaged in anything too physical I just have underpants on. Maybe in the evening particularly if I have a drink I may wear some padded underpants...If I play golf I wear the sheath system....I have found that if I go out for the evening for a meal or maybe a couple of drinks at a gathering....I do tend to wear the sheath."

"None of the three appliances in the trial are as comfortable or convenient to use as pads; it is always pleasant to use a fresh pad; none of these appliances has this feeling. However, they do have advantages, in particular the potential to enable me to go for longer periods without having to change something such as a pad, e.g. a reasonably long walk or shopping, or several hours working in the garden. Even the two hours of the clamp can provide this to a small extent when I am being active, but the two hour limit means using some kind of timer to avoid over-running by too long.......in summary, I need a reason to use one of these devices over and above simply using a pad."

Strengths and limitations of each product are summarised in Table 6.

\section{Overview of health economic analysis}

Views about value-for-money of products (Table 7)

First men were asked about use of pads and sheaths in various combinations for day use. The proportion stating the NHS should only provide pads (the cheapest option), was $40 \%$. Immediately after testing all products and when the relative costs were still not known by participants, less than $25 \%$ would select pads alone and higher proportions chose more expensive combinations of pads and sheaths. Three months later, when the costs were disclosed, over $70 \%$ thought the NHS should offer BWU and clamps to men, although much smaller proportions had reported using these products post testing or stated they would use them in the future.

\section{Adverse Events}

Reported adverse events were: skin reddening from the sheath $(n=1)$; blister from BWU straps $(n=1)$; and pain from penile compression device $(n=47)$. Apart from pain, the low incidence could be due to the short length of use of each device and the support of a research nurse expert in continence management.

\section{Discussion}

This is the first clinical trial comparing performance of three male-specific devices for continence management and absorbent pads, and the first to examine user preferences immediately after testing and actual use (revealed preferences) several months later. It is also the first published trial of body worn urinals (there have been clinical trials of urinary sheaths, ${ }^{15,25}$ absorbent pads, ${ }^{26}$ and penile clamps ${ }^{24,27}$ ) and thus provides valuable clinical information on the differences between products, their strengths and limitations, and the need for individual support in choice of products for different activities. 
Of note are the substantial differences found in product performance and an important finding was the extent to which men found benefit from using a mix of products, often for different activities or circumstances. Around two thirds continued to use at least one device in addition to absorbent pads 3 months after testing.

Most men in this study had light incontinence (determined by usual pad size) and all had been treated for prostate cancer. This population differs from that reported by Chartier-Kastler ${ }^{15}$ who studied men with moderate/heavy incontinence (any cause) when wearing a sheath drainage system compared to their usual pads. Participants in that study reported significantly better quality of life with sheaths and around two thirds preferred sheaths to pads. We also found that men had significantly better quality of life initially following sheath testing (and BWU ) and around a third stated that they preferred to use a sheath but almost always in combination with pads and/or other devices. Our study supports the provision of sheaths but usually as part of a mix with other pads and devices rather than as an alternative.

At study entry, 55\% had used at least one of the devices (usually a sheath). Most who had tried devices had done so with apparently little, if any, support from HCPs; 97\% reported fitting their own devices unaided. Study participants received expert guidance to ensure maximum success with each device and the acceptability of devices probably indicates the importance of good fitting and support. ${ }^{12}$

Typically men in the UK do not pay for their pads or devices as they are supplied freely within the tax-funded NHS. However, cost sensitivity was shown by some participants. Immediately after product testing, when relative prices were not known to them, men stated that they would prefer the more expensive containment option of a mix of sheaths and pads. When relative costs were revealed three months post testing, most men agreed that the NHS should provide BWU and clamps as well as pads and sheaths.

Important short-comings of device designs were revealed. The BWU design was generally less successful than the sheath and most men who could use a sheath would do so in preference to the BWU. Sheaths are difficult to use for men with a short or retracted penis and, although the BWU is designed for this purpose, men experienced difficulty in keeping the BWU in place. The BWU design was also considered the most unappealing design with the worst impact on self-image. The clamp had important strengths in continence control but also caused discomfort and pain. A substantial proportion of men may not receive good information and advice about products. To help provide men with fitting information our team produced a video on successful sheath application. ${ }^{26}$

\section{Limitations}

Despite the extensive mail-out, recruitment target was not achieved in the time and resources available. Not all continence pad delivery services were able to identify men who had prostate cancer and some men did not participate because of fear of jeopardizing their pad supply. Not all urology services routinely asked men whether they experienced continence problems and thus were unable to assist with recruitment.

Most men had light incontinence. A study focusing on men with moderate/heavy incontinence may show that the preferred product combinations are different. 
No validated tool for assessing quality of life of pad or device use is available and although we carried out a brief validation of our questionnaire and based it on one that had been previously tested for reliability in another study, our questions may not have included all the items of importance to $\mathrm{pad} / \mathrm{device}$ users.

\section{Recommendations for research}

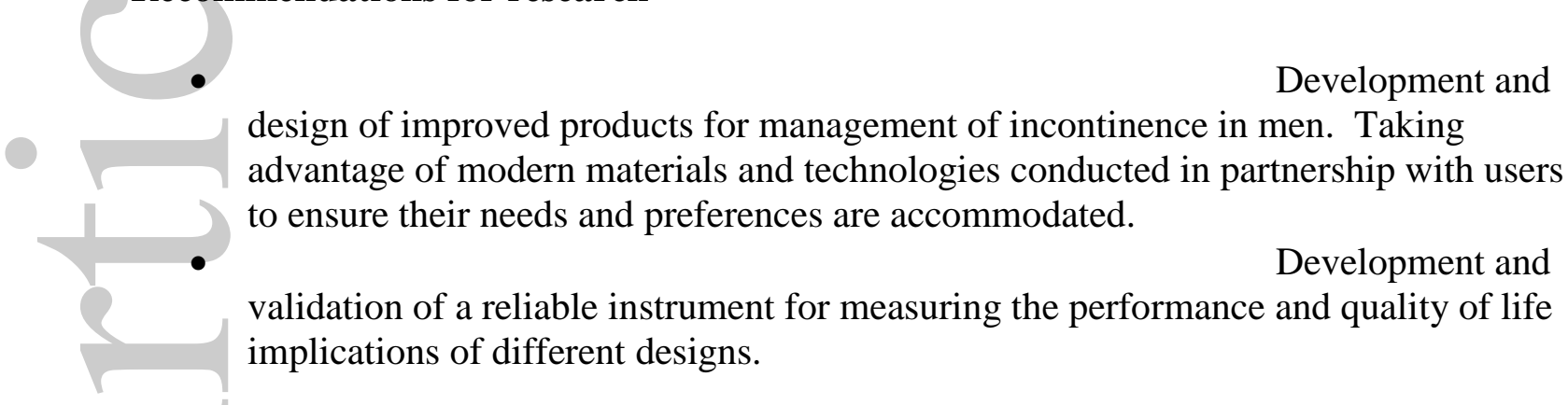

\section{Recommendations for practice}

The findings have several implications for clinical practice. Better information and advice about continence products for men is needed to inform and support health care professionals and patients. During routine follow-up of prostate cancer treatment, men should be asked about the presence of urinary incontinence, and how it affects their daily life. Containment products can be tailored to men's needs depending on the sport/leisure/work and social activities that they do, or would like to do. Men should be offered information about all types of absorbent pads and male devices and how to obtain products to try. In general, a sheath system should be tried before a BWU, but individual advice on fitting is required to maximise chances of success. Clamps are an effective option, but for short periods only, and provided cognitive ability, manual dexterity and bladder and genital sensation enable safe use.

\section{Conclusion}

The three devices and absorbent pads have different strengths and limitations that make them more (or less) suitable for particular activities. Most men prefer to use a combination of devices and pads in order to meet their lifestyle needs. Where products are provided by health services, combinations of devices and absorbent products should be offered together with skilled fitting and support, in order to provide optimum continence management.

Funding: Prostate Cancer UK (formerly the Prostate Cancer Charity) Grant 110841

Acknowledgements: Ms. Deborah Knight University of Southampton

Jade-Euro-Med LTD and SG\&P Payne for fitting the body worn urinals.

\section{Conflicts of Interest}

All authors received funding from the Prostate Cancer Charity during the course of this study.

In addition:

Alan Cottenden undertook consultancy work for SAC AB during the conduct of this study. 
Miranda Fader reports grants from SCA AB during the conduct of this study.

Brian Birch reports personal fees from Astellas (as ad hoc member of advisory group) and sponsorship to attend conferences from Astellas and Pfizer outside of the submitted work.

No other conflicts of interest exist.

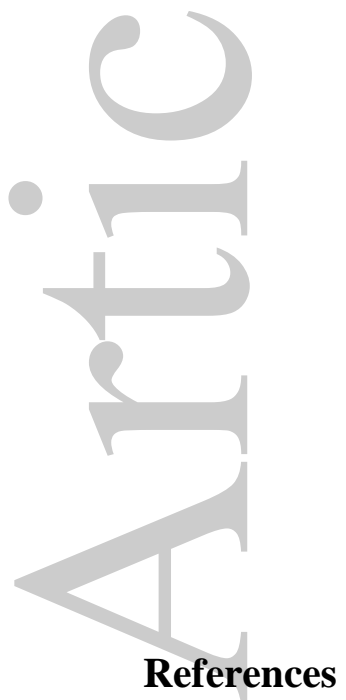

1. Cancer Research UK. Cancer incidence for common cancers. 2014; Available at: http://www.cancerresearchuk.org/cancer-info/cancerstats/incidence/commoncancers/. Accessed May 21, 2014.

2. Hunskaar S, Burgio KL, Clark A. Epidemiology of urinary and faecal incontinence and pelvic organ prolapse. In: Abrams P, Cardozo L, Khoury S, Wein AJ, editors. Incontinence. Proceedings of 3rd International Consultation on Incontinence. Plymouth, UK: Health Publications Ltd 2004, Plymbridge Distributors Ltd; 2004.

3. Fontaine E, Izadifar V, Barthelemy Y, et al. Urinary continence following radical prostatectomy assessed by a self-administered questionnaire. Eur Urol 2000;37:223-227.

4. Wilt TJ, Ahmed HU. Prostate cancer screening and the management of clinically localized disease. BMJ 2013;346:28-37.

5. Office for National Statistics. Population ageing in the United Kingdom, its constituent countries and the European Union. 2012; Available at:

http://www.ons.gov.uk/ons/dcp171776_258607.pdf. Accessed May 21, 2014.

6. Kirschner-Hermanns R, Jakse G. Quality of life following radical prostatectomy. Crit Rev Oncol 2002;43:141-151.

7. Resendes LA, McCorkle R. Spousal responses to prostate cancer: an integrative review. Cancer Invest 2006;24:192-198. 
8. Sharpley CF, Bitsika V, Christie DR. Understanding the causes of depression among prostate cancer patients: development of the Effects of Prostate Cancer on Lifestyle Questionnaire. Psychooncology 2009;18:162-168.

9. Paterson J. Stigma associated with postprostatectomy urinary incontinence. J Wound Ostomy Continence Nurs 2000;27:168-173.

10. Mazur DJ, Merz JF. Older patients' willingness to trade off urologic adverse outcomes for a better chance at five-year survival in the clinical setting of prostate cancer. $\mathrm{J} \mathrm{Am}$ Geriatr Soc 1995;43:979-984.

11. Sanda MG, Dunn RL, Michalski J, et al. Quality of life and satisfaction with outcome among prostate-cancer survivors. N Engl J Med 2008;358:1250-1261.

12. Cottenden AM, Bliss DZ, Fader MJ, et al. Management with continence products. In: Abrams P, Cardozo L, Khoury S, Wein AJ, editors. Incontinence. Proceedings of 5th International Consultation on Incontinence. 5th ed. Plymbridge, UK: Health Publications $2013 ; 2013$.

13. National Institute for Health and Clinical Excellence May 2010. The management of lower urinary tract symptoms in men. 2010.

14. Lucas MG, Bosch RJ, Burkhard FC, et al. EAU guidelines on assessment and nonsurgical management of urinary incontinence. Eur Urol 2012;62:1130-1142.

15. Chartier-Kastler E, Ballanger P, Petit J, et al. Randomized, crossover study evaluating patient preference and the impact on quality of life of urisheaths vs absorbent products in incontinent men. BJU Int 2011;108:241-247.

16. Armitage P, Berry G. Statistical methods in medical research. 3rd ed. Oxford: Blackwell Scientific Publications; 1994.

17. Mahoney FI, Barthel DW. Functional Evaluation: the Barthel Index. Md State Med J 1965;14:61-65.

18. Folstein MF, Folstein SE, McHugh PR. "Mini-mental state". A practical method for grading the cognitive state of patients for the clinician. J Psychiatr Res 1975;12:189-198.

19. Okamura K, Nojiri Y, Osyga Y. Reliability and validity of the King's Health Questionnaire for lower urinary tract symptoms in both genders. . BJU Int 2009;103:1673-1678.

20. Margolis MK, Vats V, Coyne KS, et al. Establishing the content validity of the King's Health Questionnaire in men and women with overactive bladder in the US. . PatientCentered Outcomes Research 2011;4:177-187.

21. DHL Supply Chain Limited as agent for NHS Business Services Authority. NHS supply chain. 2014; Available at: http://www.supplychain.nhs.uk/. Accessed May 21, 2014. 
22. Curtis L. Unit costs of health and social care 2011. 2011; Available at: http://www.pssru.ac.uk/archive/pdf/uc/uc2011/uc2011.pdf. Accessed May 21, 2014.

23. NHS Information Centre for Health and Social Care. Prescription cost analysis, England. 2011; Available at: http://data.gov.uk/dataset/prescription-cost-analysis-england. Accessed May 21, 2014.

24. Moore KN, Schieman S, Ackerman T, et al. Assessing comfort, safety, and patient satisfaction with three commonly used penile compression devices. Urology 2004;63:150-154.

25. Fader M, Pettersson L, Dean G, et al. Sheaths for urinary incontinence: a randomized crossover trial. BJU Int 2001;88:367-372.

26. International Consultation on Incontinence (ICI), Internationa Continence Society (ICS) 2014. Continence product advisor. 2014; Available at:

http://www.continenceproductadvisor.org/. Accessed May 21, 2014.

27. Barnard J, Westenberg AM. The penile clamp: Medieval pain or makeshift gain? Neurourol Urodyn 2014.

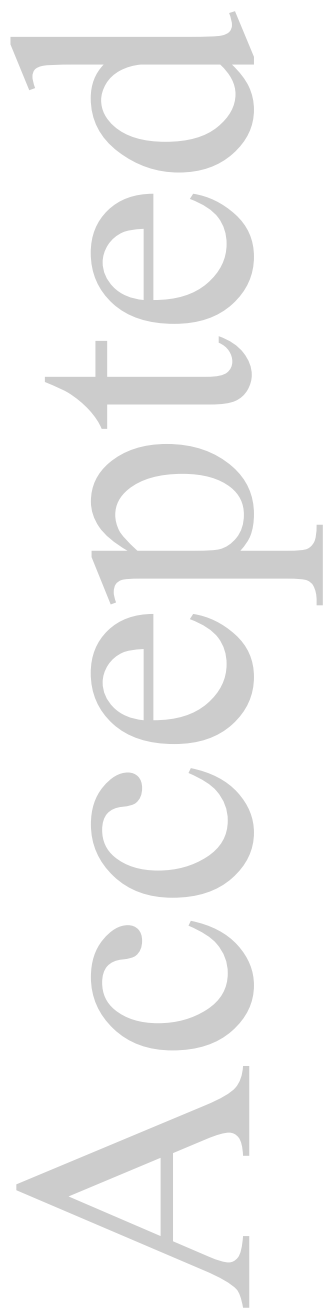

This article is protected by copyright. All rights reserved. 
Figure 1: Crossover trial design and progression through the study

Visit 1: Baseline assessment:

Demographics, continence status, Barthel Score, MMSE and KHQ

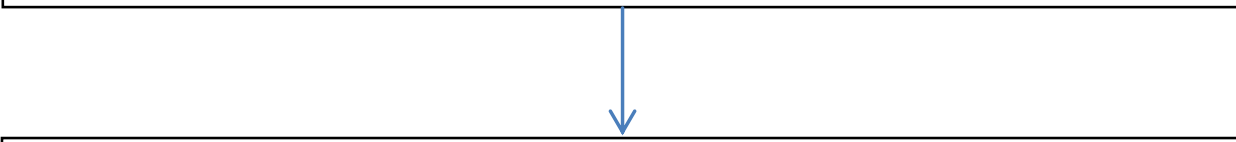

Randomised centrally in blocks of 6
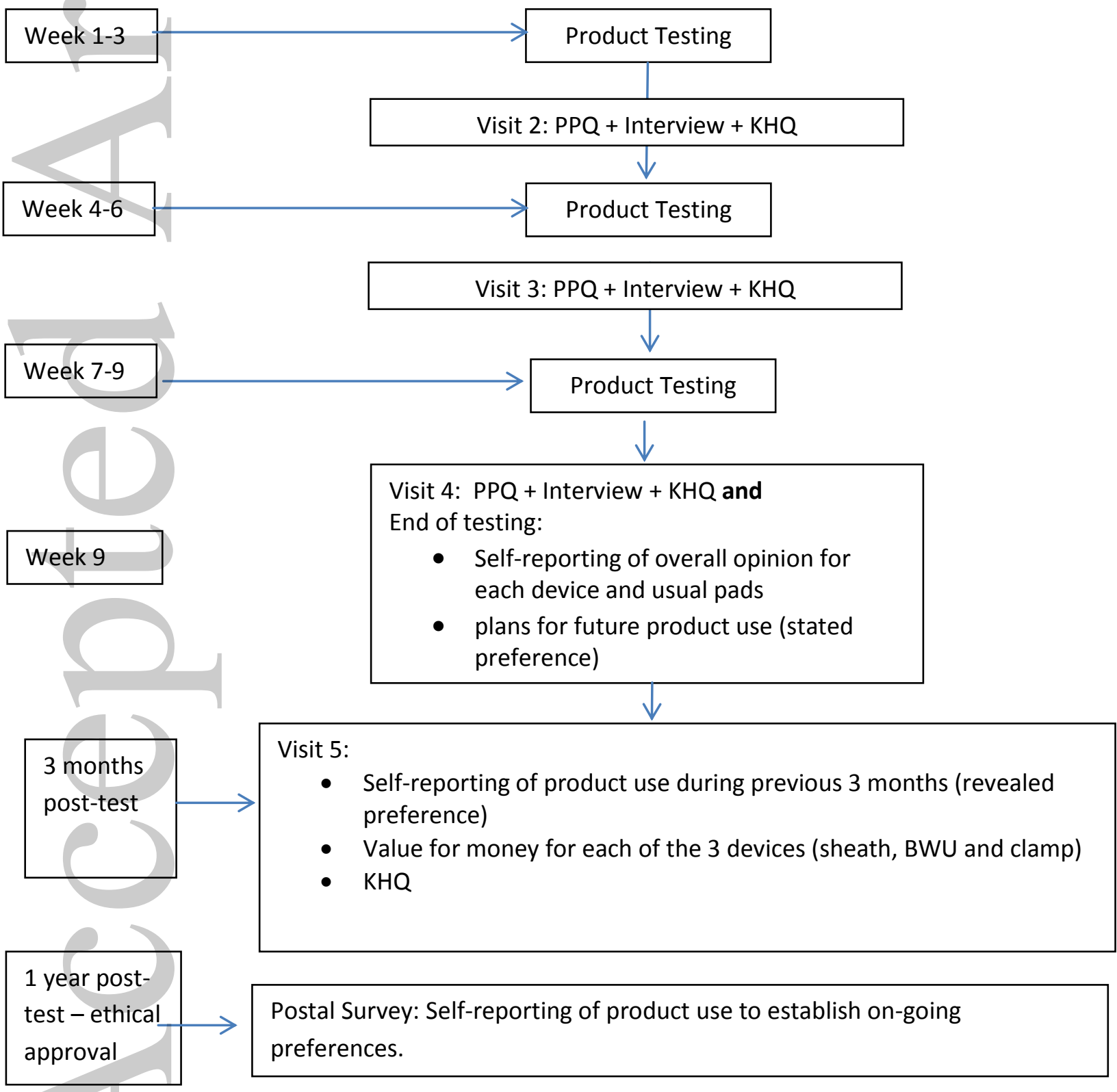

$\mathrm{KHQ}=$ Kings Health Quality of Life questionnaire

MMSE = Mini Mental State Exam

$P P Q=$ Product performance questionnaire

This article is protected by copyright. All rights reserved. 


\begin{tabular}{|c|c|c|}
\hline \multicolumn{3}{|c|}{ Figure 2: Details of products used in the study } \\
\hline Product type & Design & $\begin{array}{c}\text { Brand (Dispensing } \\
\text { Appliance Contractor } \\
\text { (DAC)) }\end{array}$ \\
\hline & $\begin{array}{l}\text { Varied - Participant's current pad } \\
\text { (standard care) }\end{array}$ & NHS Trust or self-purchase \\
\hline Sheath & 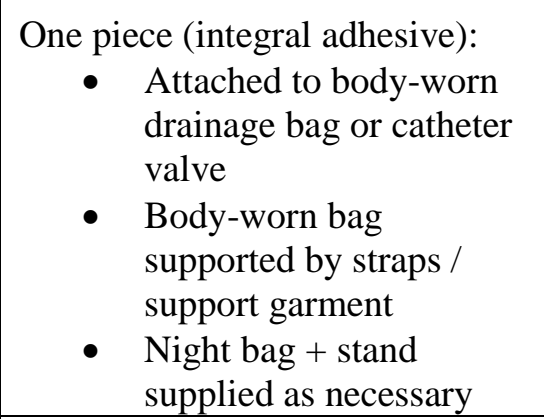 & $\begin{array}{l}\text { Conveen Optima (Coloplast } \\
\text { Ltd.) } \\
\text { P-Sure (Manfred Sauer) } \\
\text { Clear Advantage (Rochester } \\
\text { Medical) } \\
\text { (shorter length versions used } \\
\text { when available) }\end{array}$ \\
\hline & $\begin{array}{l}\text { Rubber cone }+ \text { flange (One or } \\
\text { two piece): } \\
\text { - } \\
\text { Attached to body-worn } \\
\text { drainage bag or tap } \\
\text { - } \\
\text { Body-worn bag } \\
\text { supported by straps / } \\
\text { support garment } \\
\text { - } \\
\text { Night bag + stand } \\
\text { supplied as necessary } \\
\end{array}$ & $\begin{array}{l}\text { Mark } 6 \text { (SG \& P Payne) } \\
\text { Model } 101 \text { \& } 106 \text { (Jade Euro- } \\
\text { Med) }\end{array}$ \\
\hline Clamp & $\begin{array}{l}\text { Hinged clamp made from soft } \\
\text { sponge rubber and metal. } \\
\text { Available in two sizes. }\end{array}$ & $\begin{array}{l}\text { Cunningham design clamp } \\
\text { (SG\&P Payne) }\end{array}$ \\
\hline
\end{tabular}

This article is protected by copyright. All rights reserved. 
Figure 3: Consort Diagram

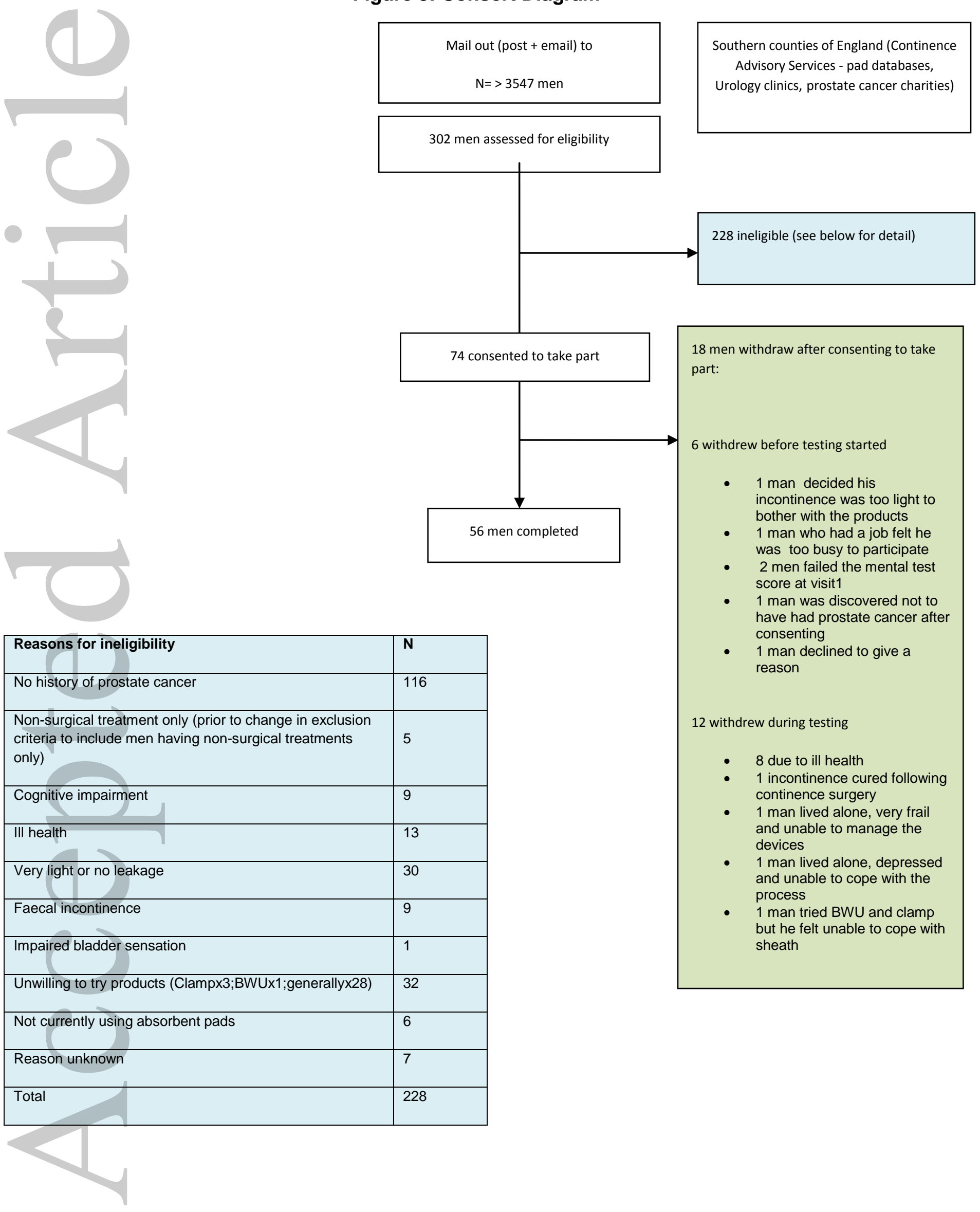

This article is protected by copyright. All rights reserved. 
Table 1: Participant characteristics-demographics, health, quality of life and incontinence ( $N=56$ men)

\begin{tabular}{|l|c|c|}
\hline Continuous variables & Mean & SD \\
\hline Age (years) & 72.2 & $\begin{array}{c}6.6 \\
\text { (Range 54-85) }\end{array}$ \\
\hline Barthel score. 0= total dependence, 100 = independent) & 92.5 & 3.6 \\
\hline KHQ max 100; high score = low continence-related QOL & 39.6 & 11.5 \\
\hline Time between first treatment and entering study (years) & 7.5 & 5.1 \\
\hline \\
Frequencies: $\mathbf{n}$ (\%)
\end{tabular}

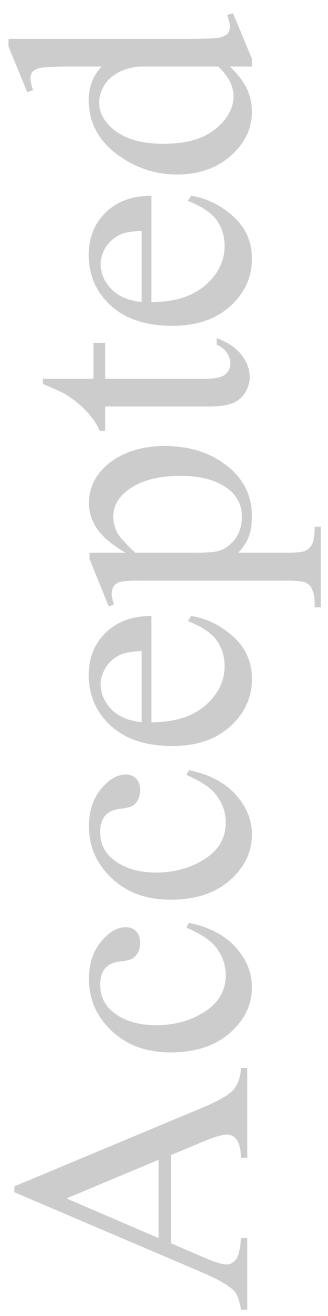

This article is protected by copyright. All rights reserved. 


\begin{tabular}{|c|c|c|c|c|}
\hline $\begin{array}{c}\text { Employment } \\
\mathrm{N}=41 \text { responses }\end{array}$ & $\begin{array}{c}\text { Retired } \\
35(85.4) \\
\end{array}$ & $\begin{array}{c}\text { Full-time } \\
1(2.4) \\
\end{array}$ & $\begin{array}{c}\text { Part-time } \\
4(9.8) \\
\end{array}$ & $\begin{array}{c}\text { Seeking work } \\
1(2.4) \\
\end{array}$ \\
\hline $\begin{array}{l}\text { Type of } \\
\text { incontinence }\end{array}$ & \multicolumn{2}{|c|}{$\begin{array}{l}\text { Stress Urinary Incontinence(SUI) } \\
38 \text { (67.9) }\end{array}$} & \multicolumn{2}{|c|}{$\begin{array}{c}\text { Mixed } \\
(\mathrm{SUI}+\text { Urge incontinence) } \\
18(32.1)\end{array}$} \\
\hline $\begin{array}{l}\text { Severity of } \\
\text { incontinence }\end{array}$ & $\begin{array}{l}\text { Light } \\
38(67.9)\end{array}$ & $\begin{array}{l}\text { Moderate / } \\
\text { heavy } \\
18(32.1)\end{array}$ & \multicolumn{2}{|c|}{$\begin{array}{l}\text { Light = using small insert, pouch, leaf } \\
\text { Moderate/heavy if using medium/large } \\
\text { insert, diaper, pull-up }\end{array}$} \\
\hline $\begin{array}{l}\text { Primary } \\
\text { treatment for } \\
\text { prostate cancer }\end{array}$ & \multicolumn{4}{|c|}{$\begin{array}{c}\text { TURP + RT } 2(3.5) \\
\text { HIFU } 4 \text { (7.1) } \\
\text { Radiotherapy } 6(10.7)\end{array}$} \\
\hline $\begin{array}{l}\text { Typical product } \\
\text { use: }\end{array}$ & \multicolumn{2}{|c|}{ Pads only } & \multicolumn{2}{|c|}{ Sheaths and pads } \\
\hline Day & \multicolumn{2}{|c|}{$48(85.7)$} & \multicolumn{2}{|c|}{$8(14.2)$} \\
\hline $\begin{array}{l}\text { Night : None, } \mathrm{n}= \\
18(32.1)\end{array}$ & \multicolumn{2}{|c|}{$35(62.5)$} & \multicolumn{2}{|c|}{$3(5.4)$} \\
\hline Previous product & Tried sheath? & Tried BWU? & Tried clamp? & $\begin{array}{l}\text { Had help with } \\
\text { fitting these } \\
\text { products }(\mathrm{N}=34)\end{array}$ \\
\hline & $\begin{array}{l}\text { YES: } 31(55.4) \\
\text { NO: } 25(44.6)\end{array}$ & $\begin{array}{l}\text { YES: } 5 \text { (8.9) } \\
\text { NO: } 51 \text { (91.9) }\end{array}$ & $\begin{array}{l}\text { YES: } 3(5.4) \\
\text { NO: } 53(94.6)\end{array}$ & $\begin{array}{c}\text { YES: } 1(2.9) \\
\text { NO: } 33(97.1)\end{array}$ \\
\hline
\end{tabular}

This article is protected by copyright. All rights reserved. 
Table 2A \& 2B: Overall opinion after testing all products

Table 2A: Visual analogue scale Range: 0 (worst opinion) - 10 (best opinion)

\begin{tabular}{|c|c|c|c|c|c|c|c|c|c|c|}
\hline & $\mathrm{N}$ & \multicolumn{2}{|c|}{ Pads } & \multicolumn{2}{|c|}{ BWU } & \multicolumn{2}{|c|}{ Sheath } & \multicolumn{2}{|c|}{ Clamp } & \multirow{2}{*}{$\begin{array}{c}\text { Significance } \\
\mathrm{P}^{*}\end{array}$} \\
\hline & & Mean & SD & Mean & SD & Mean & SD & Mean & SD & \\
\hline Day & $51^{* *}$ & 7.56 & 1.64 & 4.10 & 3.07 & 5.61 & 3.37 & 4.61 & 3.42 & $<0.0005$ \\
\hline home & $95 \% \mathrm{Cl}$ & \multicolumn{2}{|c|}{7.10 to 8.02} & \multicolumn{2}{|c|}{3.23 to 4.96} & \multicolumn{2}{|c|}{4.69 to 6.53} & \multicolumn{2}{|c|}{6.64 to 5.57} & \\
\hline Day & $51^{* *}$ & 7.09 & 2.16 & 3.43 & 3.04 & 5.86 & 3.62 & 3.84 & 3.37 & $<0.0005$ \\
\hline away & $95 \% \mathrm{Cl}$ & \multicolumn{2}{|c|}{6.48 to 7.70} & \multicolumn{2}{|c|}{2.58 to 4.29} & \multicolumn{2}{|c|}{4.85 to 6.88} & \multicolumn{2}{|c|}{2.89 to 4.72} & \\
\hline \multirow[t]{2}{*}{ Night } & $28^{* *}$ & 7.84 & 2.40 & 1.89 & 2.39 & 4.46 & 3.81 & \multirow{2}{*}{\multicolumn{2}{|c|}{ Not relevant }} & $<0.0005$ \\
\hline & $95 \% \mathrm{Cl}$ & $6.91 \mathrm{t}$ & 8.77 & 0.96 & 2.82 & 2.98 & 5.94 & & & \\
\hline
\end{tabular}

${ }^{*}$ Repeated measures ANOVA to test the null hypothesis of no difference in means between the 4 products

${ }^{* *} \mathrm{~N}$ is less than 56 (day use home or away) and 38 (night use) due to missing data

\begin{tabular}{|c|c|c|c|c|c|c|c|}
\hline \multirow{2}{*}{$(1)$} & & \multirow[t]{2}{*}{$\mathrm{N}^{*}$} & \multicolumn{2}{|c|}{$\begin{array}{l}\text { Not acceptable } \\
\text { / Poor }\end{array}$} & \multicolumn{2}{|c|}{$\begin{array}{c}\text { Acceptable / } \\
\text { Good }\end{array}$} & \multirow[t]{2}{*}{$\begin{array}{c}\text { Paired comparisons } \\
\text { Significances ( } p \text { values**) }\end{array}$} \\
\hline & & & $n$ & $\%$ & $n$ & $\%$ & \\
\hline \multirow{4}{*}{$\begin{array}{l}\text { Day } \\
\text { home }\end{array}$} & Pads & 56 & 4 & 7.1 & 52 & 92.9 & \multirow{4}{*}{$\begin{array}{l}\text { Pads vs. BWU: 0.0005; } \\
\text { Sheath: } 0.031 \text {; Clamp: } 0.0005 \\
\text { BWU vs. Sheath: } 0.014 ; \text { Clamp: } 0.361 \\
\text { Sheath vs. Clamp: } 0.405\end{array}$} \\
\hline & BWU & 56 & 29 & 51.8 & 27 & 48.2 & \\
\hline & Sheath & 53 & 14 & 26.4 & 39 & 73.6 & \\
\hline & Clamp & 54 & 22 & 40.7 & 32 & 59.3 & \\
\hline \multirow{4}{*}{$\begin{array}{l}\text { Day } \\
\text { away }\end{array}$} & Pads & 56 & 10 & 17.9 & 46 & 82.1 & \multirow{4}{*}{$\begin{array}{l}\text { Pads vs. BWU: } 0.0005 ; \text { Sheath: } 0.21 ; \\
\text { Clamp: } 0.001 \\
\text { BWU vs. Sheath: } 0.010 ; \text { Clamp: } 0.571 \\
\text { Sheath vs. Clamp: } 0.11\end{array}$} \\
\hline & BWU & 53 & 34 & 64.1 & 22 & 33.9 & \\
\hline & Sheath & 53 & 17 & 32.1 & 36 & 67.9 & \\
\hline & Clamp & 54 & 29 & 53.7 & 25 & 46.3 & \\
\hline \multirow[t]{2}{*}{ Night } & Pads & 44 & 4 & 9.1 & 40 & 90.9 & \multirow{3}{*}{$\begin{array}{l}\text { Pads vs. BWU: } 0.0005 \text {; Sheath: } 0.019 \\
\text { BWU vs. Sheath: } 0.013\end{array}$} \\
\hline & BWU & 33 & 28 & 84.8 & 5 & 15.2 & \\
\hline & Sheath & 31 & 15 & 48.4 & 16 & 51.6 & \\
\hline
\end{tabular}

* $N$ is less than 56 (day use home or away) and 38 (night use) due to missing data

** Paired comparisons between each pair of products using McNemar's test 
Table 3: Summary of product performance (daytime) (\% of responses indicating agreement with statement)

\begin{tabular}{|c|c|c|c|c|c|}
\hline $\mathrm{N}=56$ & & $\begin{array}{c}\text { Pad as } \\
\text { baseline/norm } \\
\% \\
\end{array}$ & $\begin{array}{c}\text { Sheath } \\
\%\end{array}$ & $\begin{array}{c}\mathrm{BWU} \\
\%\end{array}$ & $\underset{\%}{\text { Clamp }}$ \\
\hline Security & Always feels secure & 46 & 38 & 32 & $68^{v \checkmark v}$ \\
\hline Impact on clothing & $\begin{array}{l}\text { Product never affects } \\
\text { clothing choice }\end{array}$ & 38 & 42 & 38 & $68^{v \checkmark v}$ \\
\hline Pain during use & Never experience pain & 75 & 58 & $35^{x x}$ & $11^{\times \times x}$ \\
\hline Leakage & Product never leaks & 21 & $49^{r}$ & 36 & $75^{\checkmark v v}$ \\
\hline $\begin{array}{l}\text { Impact on physical self- } \\
\text { image }\end{array}$ & None & 48 & 57 & $39^{x \times}$ & 62 \\
\hline $\begin{array}{l}\text { Impact on feelings of } \\
\text { masculinity }\end{array}$ & None & 55 & 74 & 63 & 62 \\
\hline Ease of putting on & Good & $84^{\checkmark \checkmark \checkmark}$ & $43^{r}$ & 25 & $51^{\triangleleft}$ \\
\hline Ease of taking off & Good & $84^{v \checkmark v}$ & 24 & 32 & 48 \\
\hline Ability to keep skin dry & Good & 34 & 48 & 35 & $66^{v \checkmark}$ \\
\hline Kindness to skin & Good & 43 & 27 & 29 & 27 \\
\hline Comfort when dry & Good & $77^{\triangleleft}$ & $64^{2}$ & 38 & $\mathrm{n} / \mathrm{a}$ \\
\hline Comfort when wet & Good & 5 & $45^{\checkmark v}$ & $24^{2}$ & $\mathrm{n} / \mathrm{a}$ \\
\hline $\begin{array}{l}\text { Discreetness to do with } \\
\text { visibility }\end{array}$ & Good & $48^{\checkmark}$ & $54^{2}$ & 31 & 41 \\
\hline $\begin{array}{l}\text { Discreetness to do with } \\
\text { odour }\end{array}$ & Good & 38 & $69^{v v}$ & 53 & $70^{r}$ \\
\hline Ease of disposal & Good & 38 & $65^{\checkmark}$ & $\mathrm{n} / \mathrm{a}$ & $\mathrm{n} / \mathrm{a}$ \\
\hline Ease of carrying & Good & 35 & $65^{v \triangleleft}$ & 38 & $78^{\triangleleft \checkmark}$ \\
\hline Storage of spare products & Good & 46 & $73^{\checkmark v}$ & 43 & $84^{r v}$ \\
\hline
\end{tabular}

$\checkmark$ product performs significantly better for that characteristic than one, two or three of the other product(s)

$x$ product performs significantly worse for that characteristic than one, two or three of the other product(s) 


\section{Table 4: Preferred products after testing all products}

\begin{tabular}{|c|c|c|c|c|c|c|c|}
\hline & $\mathrm{N}$ & \multicolumn{2}{|c|}{ Pads only } & \multicolumn{2}{|c|}{ Pads and other } & \multicolumn{2}{|c|}{ Other(s) only } \\
\hline & & $\mathrm{n}$ & $\%$ & $\mathrm{n}$ & $\%$ & $\mathrm{n}$ & $\%$ \\
\hline \multirow{2}{*}{$\begin{array}{l}\text { Day } \\
\text { home }\end{array}$} & 56 & 13 & 23.2 & 37 & 66.1 & 6 & 10.7 \\
\hline & & & & \multicolumn{2}{|c|}{$\begin{array}{l}\text { Pads \& Sheath (9); Pads \& BWU (5); } \\
\text { Pads and Clamp (9); Pads, Sheath, } \\
\text { Clamp (5); Pads, Sheath, BWU (2); } \\
\text { Pads, BWU, Sheath (1); all } 4 \text { (6) }\end{array}$} & \multicolumn{2}{|c|}{$\begin{array}{l}\text { BWU (1); Sheath (2) } \\
\text { Sheath \&Clamp (2); } \\
\text { Sheath \& BWU (1) }\end{array}$} \\
\hline \multirow{2}{*}{$\begin{array}{l}\text { Day } \\
\text { away }\end{array}$} & 56 & 8 & 14.3 & 37 & 66.1 & 11 & 19.6 \\
\hline & & & & \multicolumn{2}{|c|}{$\begin{array}{l}\text { Pads \& Sheath (14); Pads \& BWU } \\
\text { (8); Pads and Clamp (4); Pads, } \\
\text { Sheath, Clamp (7); Pads, BWU, } \\
\text { Sheath (1); Pads, BWU, Clamp (1); } \\
\text { all } 4 \text { (2) }\end{array}$} & \multicolumn{2}{|c|}{$\begin{array}{l}\text { BWU (2); Sheath (4); } \\
\text { Sheath \&Clamp (3); } \\
\text { Sheath \& BWU (1); } \\
\text { BWU \& Clamp (1) }\end{array}$} \\
\hline Night & 45 & 44 & 99.8 & 1 & 0.2 & 0 & \\
\hline & & & & \multicolumn{2}{|c|}{ Pads \& Sheath } & & \\
\hline
\end{tabular}


Table 5: King's Health Questionnaire Score Range: $0=$ Best to $100=$ Worst QOL

\begin{tabular}{|c|c|c|c|c|}
\hline & Mean score at baseline & $\begin{array}{c}\text { Mean score after } \\
\text { testing device }\end{array}$ & $\begin{array}{c}\text { Difference between } \\
\text { the means (95\% CI) }\end{array}$ & $\begin{array}{c}\text { Significance } \\
<\mathbf{0 . 0 0 0 5}\end{array}$ \\
\hline Sheath & 39.95 & 35.95 & $-4.0(-6.36,-1.73)$ & $\mathrm{p}=0.001$ \\
\hline BWU & 39.23 & 36.98 & $-2.25(-3.76,-0.74)$ & $\mathrm{p}=0.004$ \\
\hline Clamp & 39.13 & 37.83 & $-1.29(-2.98,0.4)$ & $\mathrm{p}=0.131$ \\
\hline
\end{tabular}

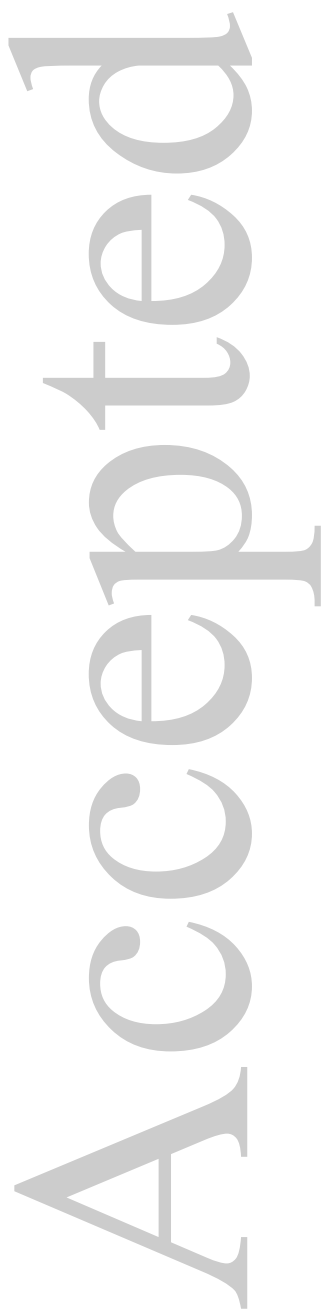

This article is protected by copyright. All rights reserved. 


\section{Table 6: Product strengths and limitations based on summary of subjective comments}

\begin{tabular}{|c|c|c|c|c|}
\hline & Pad & Sheath + bag & BWU & Clamp \\
\hline Strengths & $\begin{array}{l}\text { - } \text { Easy to apply \& } \\
\text { remove } \\
\text { - } \text { Comfortable when } \\
\text { dry } \\
\text { - Kind to skin } \\
\text { - Best for night use }\end{array}$ & $\begin{array}{l}\text { - Used for long } \\
\text { periods without } \\
\text { changing } \\
\text { - Easy to store, low } \\
\text { risk of odour } \\
\text { - } \text { Discreet emptying }\end{array}$ & $\begin{array}{l}\text { - Could be used for } \\
\text { long periods without } \\
\text { changing } \\
\text { - Washable }\end{array}$ & $\begin{array}{l}\text { - Secure } \\
\text { - Simple to remove }\end{array}$ \\
\hline Limitations & $\begin{array}{l}\text { - Bulk, leakage, } \\
\text { odour } \\
\text { - Moves around in } \\
\text { clothing } \\
\text { - Frequent changing } \\
\text { - Disposal \& change } \\
\text { in public toilets } \\
\text { - Uncomfortable } \\
\text { when wet }\end{array}$ & 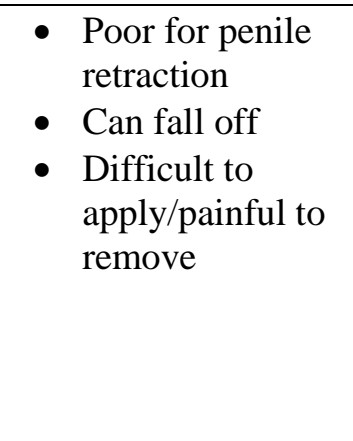 & $\begin{array}{l}\text { - Cumbersome/ } \\
\text { - Chafing of straps } \\
\text { - Will leak in certain } \\
\text { positions - esp. } \\
\text { sitting down } \\
\text { - Penis can slip out }\end{array}$ & $\begin{array}{l}\text { - } \text { Pain/discomfort } \\
\text { - Can only be worn for } \\
\text { short periods }\end{array}$ \\
\hline
\end{tabular}

This article is protected by copyright. All rights reserved. 
Table 7: Views on value-for-money of products

\section{a) PADS and SHEATHS}

Information $\quad$ • Most men receiving continence products from the NHS are given only pads. On average, if given to participants about costs they are only using pads during the day, they are given 3 pads per day. This costs the NHS about $£ 15$ per month

- The cost to the NHS of providing pads, and sheaths and accessories for use three times per week is about $£ 42$ per month

- The cost to the NHS of providing only sheaths and accessories for daily use is about $£ 58$ per month

- The cost of sheaths is based on manufacturers' recommendations (i.e. one sheath per 24 hours) irrespective of whether sheaths are used exclusively or in combination with pads

Question

asked Bearing in mind the relative costs of these options, choose one option that you think the NHS

Responses

$\mathbf{N}=47$ should provide:

Product for day use

Monthly cost to

Number $(\%)$ choosing

Only pads (no sheaths) NHS option

Sheaths on 3 days, pads on 4 days

Only sheaths (no pads)

Sheath + one pad every day

\begin{tabular}{c|c} 
& option \\
$£ 15$ & $19(40.4 \%)$ \\
$£ 42$ & $11(23.4 \%)$ \\
$£ 58$ & $2(4.3 \%)$ \\
$£ 63$ & $15(31.9 \%)$
\end{tabular}

b) BWU

Information given on costs

To provide a man with a body worn urinal costs the NHS about $£ 68$ for a urinal plus about $£ 1.80$ per bag used; manufacturers state a BWU can be expected to last about 6-12 months if used regularly, longer if less frequently.

\section{Question} Select the statement that best describes your views about BWU:

Responses $\mathbf{N}=52$ I think the NHS should offer men only the body worn urinal for day use (i.e. The NHS should not provide pads or sheaths)

I think the NHS should offer men the body worn urinal for day use in addition to other products such as pads and sheaths

I think the NHS should NOT offer men the body worn urinal for day use

c) CLAMP

Information given on costs

\section{Question}

Responses

$\mathbf{N}=\mathbf{5 1}$

To provide a man with a clamp costs the NHS about $£ 30$ per clamp, and manufacturers indicate that a clamp can be expected to last for up to 12 months or longer depending on frequency of use. Reminder that the clamp is only for day use.

Select the statement that best describes your views about the clamp:

Notes on

Notes on derivation of costs

\begin{tabular}{l} 
I think the NHS should offer men the clamp for day use in addition \\
to other products such as pads and sheaths \\
\hline I think the NHS should NOT offer men the clamp for day use
\end{tabular}

$39(76.5 \%)$

All costs were rounded to make comparisons easier.

Pad cost estimates from prices in the NHS Supply Chain catalogue ${ }^{23}$, and based on information from men recruited early in the study about the number and type of products they received from continence services. Median price (14p per pad) in Rothwell absorbency bands 7-8 (light - moderate absorbency) was used. Most men reported using 3 pads per day (day use only). The average costs of BWU, sheaths and clamps were taken from the Online Formulary data ${ }^{21}$ : sheaths assumed 1 per day @£1.55 each; leg bags, 1 per week @ £2.50; bag support garments , 1 every 2 weeks @ $£ 2$ each. Clamp (Cunningham): priced at $£ 26$. Fitting costs of sheaths and clamps were not included. This would usually be done by district nurses (NHS unit costs of home visit for 30 minutes: $£ 35$ [26]. BWU: mean of two available brands: $£ 67$, includes price of fitting by dispensing appliance producer. Leg bags and support garments are extra, as for sheaths. 